\title{
Effect of Sowing Windows on Growth and Yield of Groundnut (Arachis hypogaea L.) Genotypes
}

\author{
K. Raagavalli*, T. M.Soumya, H.K. Veeranna, S.P. Nataraju and H. Narayanswamy \\ Department of Agronomy, College of Agriculture, University of Agricultural and \\ Horticultural Sciences, Shivamogga - 577204 \\ *Corresponding author
}

\section{Keywords}

Groundnut, Growth parameters, Yield, genotype and sowing windows

Article Info

Accepted:

04 February 2019

Available Online:

10 March 2019

\section{A B S T R A C T}

In general groundnut (Arachis hypogaea L.) crop is subjected to varied climatic conditions and monsoon vagaries in particular, as it is mostly grown under rainfed conditions during Kharif. It is necessary to select a suitable groundnut genotype and sowing window as a non-monetary input to reduce the effect of climate on crop yield. Field experiment was conducted at AHRS, Bavikere, UAHS, Shivamogga, to study the influence of sowing windows on growth and yield of groundnut genotypes under rainfed conditions during Kharif-2017 in sandy loam soil. The four groundnut genotypes viz., GKVK-5, GPBD-4, G2-52 and TMV-2 and four sowing windows viz., II fortnight of June, I fortnight of July, II fortnight of July and I fortnight of August were selected. The experiment was laid out in Randomized Complete Block Design with factorial concept using two factors, each with four levels replicated thrice. The experimental results revealed that, the genotype GKVK-5 recorded significantly higher pod yield $\left(16.73 \mathrm{q} \mathrm{ha}^{-1}\right)$, shelling percentage and kernel yield. While, the crop sown during II fortnight of June recorded significantly higher pod yield, shelling percentage and kernel yield compared to delay in sowing. As delay in sowing decreased the crop growth and development.

\section{Introduction}

Groundnut is an important oilseed crop grown under rainfed conditions. It is a very sensitive crop to climatic variations, especially rainfall, temperature and radiation (Banik et al., 2009). As the crop is grown under rainfed conditions, adequate soil moisture is required during pegging and pod development stages, to get better yield. Prathima et al., (2012) reported that the photosynthetic activity of the crop is severely affected under moisture stress conditions, which reduces the crop growth and development, thereby, reducing the pod yield. Further, lack of moisture during pegging and pod filling, reduces the number of pods per plant, while that during pod development produces shriveled seeds and thereby, reduces the pod yield. Variation in any of the weather parameter causes reduction in the pod yield. Thus, it is necessary to grow the genotype which can withstand weather aberrations by adapting to varied sowing windows. Nagaeswara Rao (1992) revealed that improved genotypes contribute 25 to 28 per cent to the yield increase, while improved 
management practices contributed 30 to 32 per cent. Hence, an investigation was conducted to study the influence of sowing windows on growth and yield of groundnut genotypes.

\section{Materials and Methods}

Field experiment was conducted at AHRS, Bavikere, UAHS, Shivamogga during Kharif2017 under rainfed conditions. The soil of the experimental site was sandy loam with acidic $\mathrm{pH}$ (5.7), $1.73 \mathrm{~g} \mathrm{~kg}^{-1}$ organic carbon, 220.90:34.30:167.40 kg available $\mathrm{N}, \mathrm{P}_{2} \mathrm{O}_{5}$, $\mathrm{K}_{2} \mathrm{O} \mathrm{ha}^{-1}$. The experiment was laid out in randomized block Design with factorial concept, containing sixteen treatment combinations with three replications.

The groundnut genotypes and sowing windows were the two factors, each with four levels. The four genotypes selected were GKVK-5, GPBD-4, G2-52 and TMV-2, while the four sowing windows were II fortnight of June, I fortnight of July, II fortnight of July and I fortnight of August. Nutrients were applied @ 25:50:25 kg NPK ha ${ }^{-1}$ in the form of urea, SSP and MOP, respectively along with $10 \mathrm{t}$ of farm yard manure. Gypsum was applied during the time of ear thing up @ 500 $\mathrm{kg} \mathrm{ha}^{-1}$.

The seeds were sown at a depth of $5 \mathrm{~cm}$ with $30 \times 15 \mathrm{~cm}$ spacing. The data on the parameters like number of branches per plant, leaf area $\left(\mathrm{dm}^{2}\right.$ plant $\left.{ }^{-1}\right)$, total dry matter $(\mathrm{g}$ plant $\left.^{-1}\right)$, pod yield $\left(\mathrm{q} \mathrm{ha}^{-1}\right)$ and shelling percentage were recorded and LAI, LAD, CGR and kernel yield were calculated from the recorded parameters. The amount of rainfall received during the crop growth period and water requirement of the crop at different growth stages are presented in Figure 1. The actual sunshine hours during the crop growth period and the normal sunshine hours of the research station is presented in Figure 2.

\section{Results and Discussion}

The weather parameters such as rainfall and sunshine played a critical role on the crop growth, which in turn decides the crop yield. Apart from the total amount of rainfall received, proper distribution of rainfall throughout the crop growth period is also important as seen in Figure 1. The crop requires $400-500 \mathrm{~mm}$ of total rainfall. Among the sowing windows, the crop sown during II fortnight of June received $444.5 \mathrm{~mm}$ of total rainfall, which was well distributed in 33 rainy days. Pod filling and pod development stage, received $(66 \mathrm{~mm}$ and $126.6 \mathrm{~mm}$ of rainfall, respectively). The data pertaining to the number of branches per plant, total dry matter and CGR are presented in table 1 . The genotype GKVK-5 recorded significantly higher number of branches per plant (10.40), total dry matter (12.99 $\left.\mathrm{g} \mathrm{plant}^{-1}\right)$ and CGR $\left(8.15 \mathrm{~g} \mathrm{~m}^{-2}\right.$ day $\left.^{-1}\right)$, which might be due to better physio-morphological characters of GKVK-5. Similar results were reported by Mohite et al., (2017).

Among the sowing windows, thecrop sown during II fortnight of June recorded significantly higher number of branches per plant (11.18), total dry matter (12.73 g plant $\left.^{-1}\right)$ and CGR (7.93 $\mathrm{g} \mathrm{m}^{-2} \mathrm{day}^{-1}$ ). This might be due to the proper distribution of rainfall during critical growth period of the crop and long day conditions exposed the crop to better sunlight for longer duration which produce more photosynthates and CGR for growth and development of the plant, during early sown conditions. Exposure of the crop to short day conditions reduces the vegetative growth and thereby reduces CGR (Meena et al., 2015). Thus, the crop sown during I fortnight of August recorded lower CGR (6.24 $\mathrm{g} \mathrm{m}^{-2}$ day $\left.^{-1}\right)$. Increase in the number of branches and crop growth rate increased the total dry matter per plant when the crop was sown during II fortnight of June. 
Table.1 Influence of different sowing windows on number of branches, total dry matter and CGR of groundnut genotypes

\begin{tabular}{|c|c|c|c|c|c|c|c|c|c|c|c|c|c|c|c|}
\hline \multirow[t]{3}{*}{ Genotypes (G) } & \multicolumn{15}{|c|}{ Sowing windows $(\mathrm{S})$} \\
\hline & \multicolumn{5}{|c|}{ Number of branches (plant ${ }^{-1}$ ) } & \multicolumn{5}{|c|}{ Total dry matter (g plant ${ }^{-1}$ ) } & \multicolumn{5}{|c|}{ CGR $\left(\mathrm{g} \mathrm{m}^{-2}\right.$ day $\left.^{-1}\right)$} \\
\hline & $\mathbf{S}_{1}$ & $\mathbf{S}_{2}$ & $\mathbf{S}_{\mathbf{3}}$ & $\mathbf{S}_{4}$ & Mean & $\mathbf{S}_{1}$ & $\mathbf{S}_{\mathbf{2}}$ & $\mathbf{S}_{3}$ & $\mathbf{S}_{\mathbf{4}}$ & Mean & $\mathbf{S}_{1}$ & $\mathbf{S}_{\mathbf{2}}$ & $\mathbf{S}_{\mathbf{3}}$ & $\mathbf{S}_{\mathbf{4}}$ & Mean \\
\hline $\mathbf{G}_{1}$ & 11.87 & 10.83 & 10.53 & 8.37 & 10.40 & 14.76 & 13.55 & 12.0 & 11.60 & 12.99 & 9.41 & 8.57 & 7.47 & 7.16 & 8.15 \\
\hline $\mathbf{G}_{2}$ & 11.10 & 10.53 & 10.07 & 7.30 & 9.75 & 12.11 & 10.46 & 9.92 & 9.84 & 10.58 & 7.49 & 6.31 & 5.94 & 5.93 & 6.42 \\
\hline $\mathbf{G}_{\mathbf{3}}$ & 11.40 & 10.77 & 10.27 & 7.80 & 10.06 & 13.09 & 12.07 & 11.4 & 10.38 & 11.73 & 8.20 & 7.49 & 7.03 & 6.31 & 7.26 \\
\hline $\mathbf{G}_{\mathbf{4}}$ & 10.33 & 8.63 & 9.17 & 7.27 & 8.85 & 10.95 & 9.89 & 9.45 & 9.34 & 9.91 & 6.63 & 5.90 & 5.62 & 5.58 & 5.93 \\
\hline \multirow[t]{2}{*}{ Mean } & 11.18 & 10.19 & 10.01 & 7.68 & 9.76 & 12.73 & 11.50 & 10.7 & 10.29 & 11.30 & 7.93 & 7.07 & 6.51 & 6.24 & 6.94 \\
\hline & \multicolumn{3}{|c|}{ S.Em \pm} & \multicolumn{2}{|c|}{ C.D. $(p=0.05)$} & \multicolumn{3}{|c|}{ S.Em \pm} & \multicolumn{2}{|c|}{ C.D. $(p=0.05)$} & \multicolumn{2}{|c|}{ S.Em \pm} & \multicolumn{3}{|c|}{ C.D. $(p=0.05)$} \\
\hline Genotypes & \multicolumn{3}{|c|}{0.11} & \multicolumn{2}{|c|}{0.32} & \multicolumn{3}{|c|}{0.13} & \multicolumn{2}{|c|}{0.37} & \multicolumn{2}{|r|}{0.24} & & \multicolumn{2}{|c|}{0.68} \\
\hline $\begin{array}{c}\text { Sowing } \\
\text { windows }\end{array}$ & \multicolumn{3}{|c|}{0.11} & \multicolumn{2}{|c|}{0.32} & \multicolumn{2}{|c|}{0.13} & & \multicolumn{2}{|c|}{0.37} & \multicolumn{2}{|r|}{0.24} & & \multicolumn{2}{|c|}{0.68} \\
\hline $\mathbf{G} \times \mathbf{S}$ & \multicolumn{3}{|c|}{0.22} & \multicolumn{2}{|c|}{0.64} & \multicolumn{2}{|c|}{0.25} & & \multicolumn{2}{|c|}{0.74} & \multicolumn{2}{|r|}{0.47} & & \multicolumn{2}{|c|}{1.36} \\
\hline \multicolumn{2}{|l|}{$\mathbf{G}_{1}$ : GKVK-5 } & \multicolumn{3}{|c|}{$\mathrm{S}_{1}:$ II fortnight of June } & \multicolumn{5}{|c|}{ DAS: Days after sowing } & NS: Nor & signifi & cant & & & \\
\hline $\mathrm{G}_{2}:$ GPBD-4 & & $\mathrm{S}_{2}:$ I fortı & ht of $\mathrm{Ju}$ & & & & & & & & & & & & \\
\hline$G_{3}: G 2-52$ & & $\mathrm{~S}_{3}:$ II fort & ght of $\mathbf{J}$ & & & & & & & & & & & & \\
\hline$G_{4}: T M V-2$ & & $\mathrm{~S}_{4}: \mathrm{I}$ fortı & ht of $A$ & ust & & & & & & & & & & & \\
\hline
\end{tabular}


Table.2 Influence of different sowing windows on leaf area, LAI and LAD of groundnut genotypes

\begin{tabular}{|c|c|c|c|c|c|c|c|c|c|c|c|c|c|c|c|}
\hline \multirow[t]{3}{*}{ Genotypes (G) } & \multicolumn{15}{|c|}{ Sowing windows (S) } \\
\hline & \multicolumn{5}{|c|}{ Leaf area $\left(\mathrm{dm}^{2}\right.$ plant $\left.^{-1}\right)$} & \multicolumn{5}{|c|}{ LAI } & \multicolumn{5}{|c|}{ LAD (days) } \\
\hline & $\mathbf{S}_{\mathbf{1}}$ & $\mathbf{S}_{2}$ & $\mathbf{S}_{\mathbf{3}}$ & $\mathbf{S}_{4}$ & Mean & $\mathbf{S}_{\mathbf{1}}$ & $\mathbf{S}_{2}$ & $\mathbf{S}_{\mathbf{3}}$ & $\mathbf{S}_{4}$ & Mean & $\mathbf{S}_{1}$ & $\mathbf{S}_{2}$ & $\mathbf{S}_{\mathbf{3}}$ & $\mathbf{S}_{4}$ & Mean \\
\hline $\mathbf{G}_{1}$ & 9.27 & 8.81 & 8.78 & 8.52 & 8.85 & 2.06 & 1.96 & 1.9 & 1.89 & 1.97 & 63.87 & 60.38 & 60.00 & 57.49 & 60.43 \\
\hline $\mathbf{G}_{2}$ & 9.10 & 8.54 & 7.91 & 7.88 & 8.36 & 2.02 & 1.90 & 1.7 & 1.75 & 1.86 & 61.08 & 57.09 & 54.08 & 53.40 & 56.41 \\
\hline $\mathbf{G}_{\mathbf{3}}$ & 9.17 & 8.74 & 8.45 & 7.99 & 8.59 & 2.04 & 1.94 & 1.8 & 1.78 & 1.91 & 62.83 & 59.63 & 58.08 & 55.29 & 58.96 \\
\hline $\mathbf{G}_{4}$ & 8.91 & 8.44 & 7.98 & 7.27 & 8.15 & 1.98 & 1.88 & 1.7 & 1.62 & 1.81 & 59.62 & 56.00 & 53.33 & 50.83 & 54.95 \\
\hline \multirow[t]{2}{*}{ Mean } & 9.11 & 8.63 & 8.28 & 7.92 & 8.49 & 2.02 & 1.92 & 1.8 & 1.76 & 1.89 & 61.85 & 58.27 & 56.37 & 54.25 & 57.69 \\
\hline & \multicolumn{3}{|c|}{ S.Em \pm} & \multicolumn{2}{|c|}{ C.D. $(p=0.05)$} & \multicolumn{2}{|c|}{ S.Em \pm} & & \multicolumn{2}{|c|}{ C.D. $(p=0.05)$} & \multicolumn{2}{|c|}{ S.Em \pm} & \multicolumn{3}{|c|}{ C.D. $(p=0.05)$} \\
\hline Genotypes & \multicolumn{3}{|c|}{0.07} & \multicolumn{2}{|c|}{0.19} & \multicolumn{2}{|c|}{0.01} & & \multicolumn{2}{|c|}{0.04} & \multicolumn{2}{|r|}{0.59} & & \multicolumn{2}{|c|}{1.72} \\
\hline $\begin{array}{l}\text { Sowing } \\
\text { windows }\end{array}$ & \multicolumn{2}{|r|}{0.07} & & \multicolumn{2}{|c|}{0.19} & \multicolumn{2}{|c|}{0.01} & & \multicolumn{2}{|c|}{0.04} & \multicolumn{2}{|r|}{0.59} & & \multicolumn{2}{|c|}{1.72} \\
\hline $\mathbf{G} \times \mathbf{S}$ & \multicolumn{3}{|c|}{0.13} & \multicolumn{2}{|c|}{0.39} & \multicolumn{3}{|c|}{0.03} & \multicolumn{2}{|c|}{0.09} & \multicolumn{2}{|r|}{1.19} & & \multicolumn{2}{|c|}{3.43} \\
\hline \multicolumn{2}{|l|}{$\mathbf{G}_{1}:$ GKVK-5 } & \multicolumn{3}{|c|}{$S_{1}$ : II fortnight of June } & \multicolumn{5}{|c|}{ DAS: Days after sowing } & NS: Non & signific & ant & & & \\
\hline $\mathrm{G}_{2}:$ GPBD-4 & & $\mathrm{S}_{2}$ : I fort & at of $\mathrm{J}$ & & & & & & & & & & & & \\
\hline$G_{3}: G 2-52$ & & $\mathrm{~S}_{3}$ : II for & ht of & & & & & & & & & & & & \\
\hline$G_{4}:$ TMV-2 & & $\mathrm{S}_{4}:$ I fort & at of $t$ & ust & & & & & & & & & & & \\
\hline
\end{tabular}


Table.3 Influence of different sowing windows on pod number per plant, shelling per cent and kernel yield of groundnut genotypes

\begin{tabular}{|c|c|c|c|c|c|c|c|c|c|c|c|c|c|c|c|}
\hline \multirow[t]{3}{*}{ Genotypes (G) } & \multicolumn{15}{|c|}{ Sowing windows $(\mathrm{S})$} \\
\hline & \multicolumn{5}{|c|}{ Pod number per plant } & \multicolumn{5}{|c|}{ Shelling per cent } & \multicolumn{5}{|c|}{ Kernel yield (q ha $\left.{ }^{-1}\right)$} \\
\hline & $\mathbf{S}_{1}$ & $\mathbf{S}_{2}$ & $\mathbf{S}_{\mathbf{3}}$ & $\mathbf{S}_{4}$ & Mean & $\mathbf{S}_{1}$ & $\mathbf{S}_{\mathbf{2}}$ & $\mathbf{S}_{\mathbf{3}}$ & $\mathbf{S}_{\mathbf{4}}$ & Mean & $\mathbf{S}_{1}$ & $\mathbf{S}_{2}$ & $\mathbf{S}_{\mathbf{3}}$ & $\mathbf{S}_{\mathbf{4}}$ & Mean \\
\hline $\mathbf{G}_{1}$ & 12.39 & 12.32 & 10.95 & 10.23 & 11.47 & 74.00 & 73.33 & 72.60 & 70.67 & 72.65 & 13.37 & 13.18 & 11.5 & 10.54 & 12.17 \\
\hline $\mathbf{G}_{2}$ & 11.59 & 10.25 & 8.88 & 7.71 & 9.61 & 73.33 & 72.33 & 71.33 & 63.00 & 70.00 & 10.99 & 9.58 & 8.18 & 6.28 & 8.76 \\
\hline $\mathbf{G}_{\mathbf{3}}$ & 14.43 & 13.97 & 13.37 & 11.59 & 13.34 & 73.00 & 72.00 & 69.33 & 68.33 & 70.67 & 11.81 & 11.06 & 9.52 & 8.13 & 10.13 \\
\hline $\mathbf{G}_{\mathbf{4}}$ & 8.55 & 7.93 & 7.45 & 7.00 & 7.73 & 72.27 & 71.67 & 70.33 & 61.33 & 68.90 & 8.37 & 7.70 & 7.10 & 5.82 & 7.25 \\
\hline \multirow[t]{2}{*}{ Mean } & 11.74 & 11.12 & 10.16 & 9.13 & 10.54 & 73.15 & 72.33 & 70.9 & 65.83 & 70.55 & 11.13 & 10.38 & 9.10 & 7.69 & 9.58 \\
\hline & \multicolumn{3}{|c|}{ S.Em \pm} & \multicolumn{2}{|c|}{ C.D. $(p=0.05)$} & \multicolumn{2}{|c|}{ S.Em \pm} & & \multicolumn{2}{|c|}{ C.D. $(p=0.05)$} & \multicolumn{2}{|c|}{ S.Em \pm} & \multicolumn{3}{|c|}{ C.D. $(p=0.05)$} \\
\hline Genotypes & \multicolumn{3}{|c|}{0.19} & \multicolumn{2}{|c|}{0.55} & \multicolumn{2}{|c|}{0.80} & & \multicolumn{2}{|c|}{2.31} & \multicolumn{2}{|c|}{0.14} & & \multicolumn{2}{|c|}{0.40} \\
\hline $\begin{array}{c}\text { Sowing } \\
\text { windows }\end{array}$ & & 0.19 & & 0.5 & & & 0.80 & & 2.3 & & & 0.14 & & 0.4 & \\
\hline $\mathbf{G} \times \mathbf{S}$ & & 0.38 & & 1.0 & & & 1.60 & & NS & & & 0.28 & & 0.8 & \\
\hline $\mathrm{G}_{1}$ : GKVK-5 & & $S_{1}:$ II fort & sht of $\mathrm{Ju}$ & & DAS: Da & after s & wing & & & NS: Nor & signific & ant & & & \\
\hline $\mathrm{G}_{2}:$ GPBD-4 & & $\mathrm{S}_{2}:$ I fortı & ht of Jul & & & & & & & & & & & & \\
\hline$G_{3}: G 2-52$ & & $\mathrm{~S}_{3}$ : II fort & sht of $\mathrm{Ju}$ & & & & & & & & & & & & \\
\hline$G_{4}: T M V-2$ & & $\mathrm{~S}_{4}: \mathrm{I}$ fortı & ht of $\mathrm{Au}$ & ust & & & & & & & & & & & \\
\hline
\end{tabular}


Fig.1 Water required by the crop and the amount of rainfall received during different crop growth stages

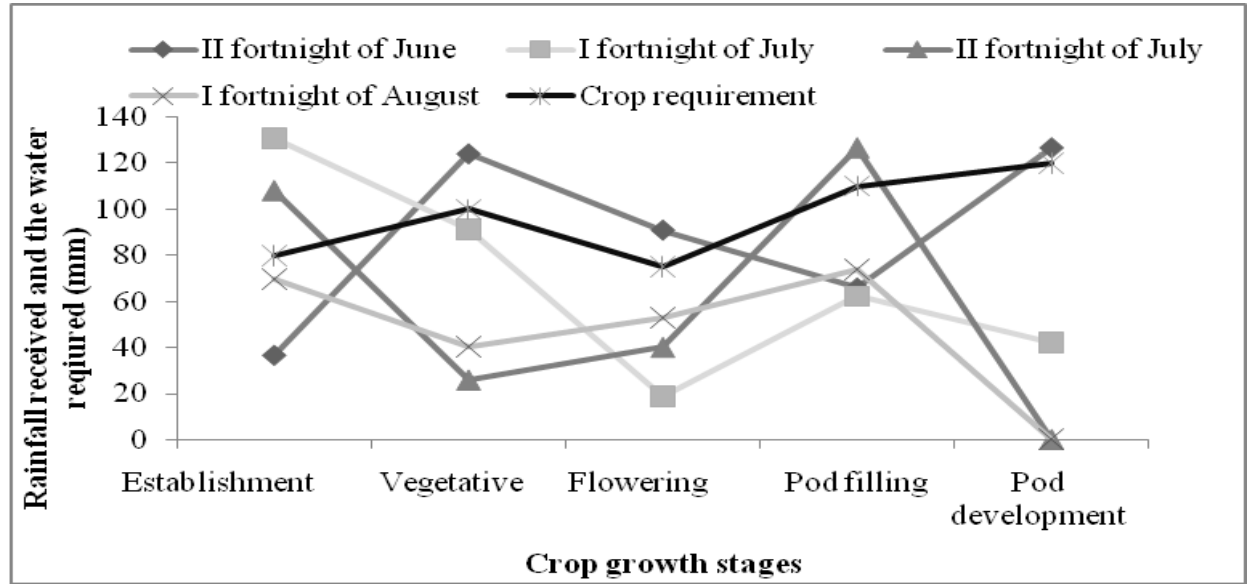

Fig.2 Actual and normal sunshine hours during the crop growth period

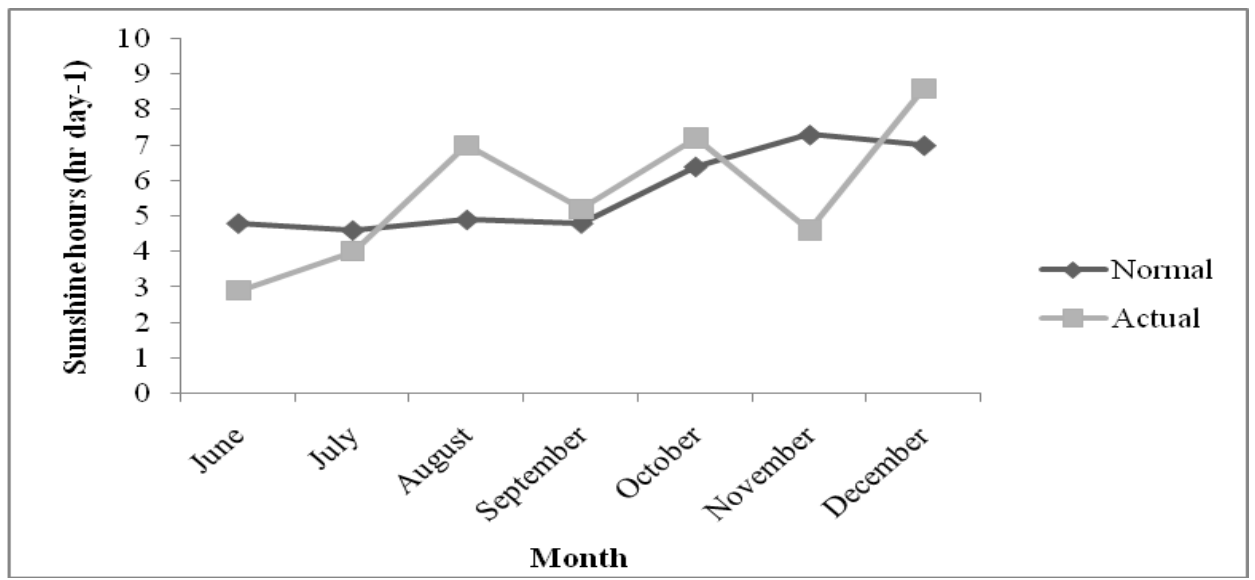

Fig.3 Influence of different sowing windows on pod yield of groundnut genotypes

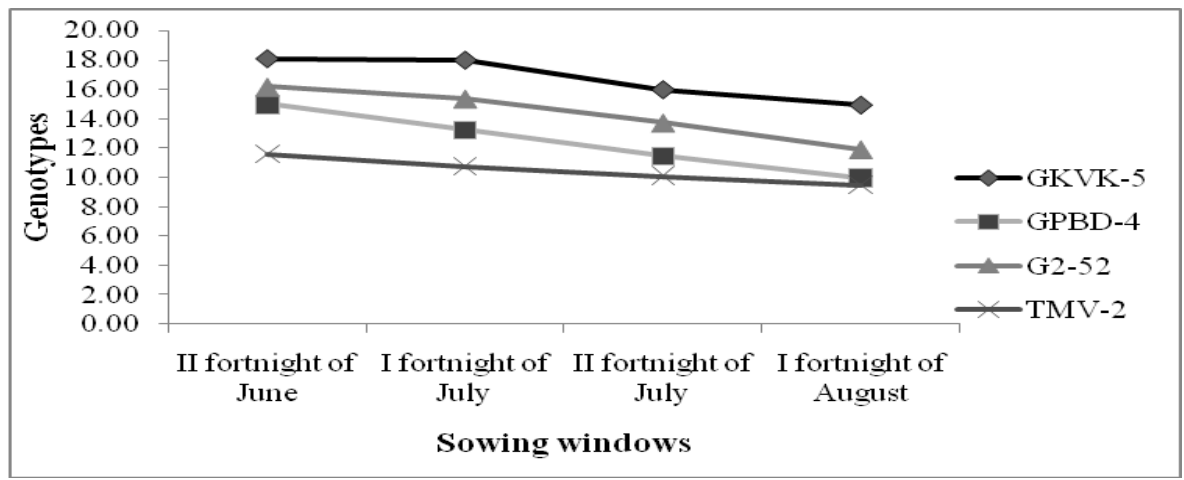


With the delay in sowing, the number of branches, total dry matter and CGR decreased during I fortnight of July, II fortnight of July and lowest during I fortnight of August. This was due to the moisture stress during late sown conditions. Prathima et al., (2012) stated that the crop growth reduces due to water stress, which reduces the assimilates of photosynthates.

The interaction effect of genotypes and sowing windows revealed that the genotype GKVK-5 (8.85 dm ${ }^{2}$ plant $^{-1}$ and 1.97, respectively) this was followed by G2-52 (8.59 $\mathrm{dm}^{2}$ plant $^{-1}$ and 1.91 , respectively), GPBD-4 (8.36 dm dlant $^{-1}$ and 1.86, respectively) and TMV-2 (8.15 dm plant $^{-1}$ and 1.81 , respectively). Increase in the leaf area was due to increase in number of branches, which increases the number of leaves per plant. Bhargavi et al., (2016) reported similar results with different spacing treatments in groundnut and stated that increase in the number of leaves increases the leaf area. Increase in the leaf area increases LAI, which further increases LAD, where the genotype GKVK-5 recorded significantly higher LAD (60.43 days), which was on par with G2-52(58.96 days) (Table 2).

The crop sown during II fortnight of June recorded significantly higher leaf area, LAI and LAD (9.11 dm2 plant $^{-1}, 2.02$ and 61.85 days, respectively) (Table 2). This was followed by the crop sown during I fortnight of July (8.63 dm plant $^{-1}, 1.92$ and 58.27 days, respectively), II fortnight of July $\left(8.28 \mathrm{dm}^{2}\right.$ plant $^{-1}, 1.84$ and 56.37 days, respectively). Delay in sowing reduced the leaf area, LAI and LAD. This might be due to the stressed condition on the plant with delay in sowing, caused by lack of rainfall which decreased from $444.5 \mathrm{~mm}$ during II fortnight of June to $236.2 \mathrm{~mm}$ during I fortnight of August. The vegetative growth reduces as the days become shorted with delayed sowing. This reduced
GKVK-5 sown during II fortnight of June recorded higher number of branches (11.87 plant $\left.^{-1}\right)$, total dry matter $\left(14.76 \mathrm{~g} \mathrm{plant}^{-1}\right)$ and CGR (9.41 $\mathrm{g} \mathrm{m}^{-2}$ day $^{-1}$ ) compared to other treatment combinations. This might be due to the combination of genetic character and also the optimum weather conditions during the crop growth. Similar results were reported by Mohite et al., (2017).

Significantly higher leaf area and LAI (Table 2) were recorded in the genotype the leaf area, as the plant cannot intercept more radiations due to short-day conditions and thereby, reduces the LAI and LAD. Agarwal et al., (1996) and Kumar et al., (2011) in niger crop reported that delay in sowing reduces the duration of vegetative growth, thereby, producing less number of leaves per plant and thus, decreased leaf area due to soil moisture stress than the early sown crop. The genotype GKVK-5 sown during II fortnight of June recorded higher leaf area (9.27 $\mathrm{dm}^{2}$ plant $\left.{ }^{-1}\right)$, LAI (2.06) and (63.87 days) compared to other treatment combinations.

Pod yield (Fig. 3) was found to be significantly higher in the genotype GKVK-5 (16.73 $\left.\mathrm{q} \mathrm{ha}^{-1}\right)$ compared to G2-52 (14.29 q $\left.\mathrm{ha}^{-1}\right)$, GPBD-4 (12.42 q ha ${ }^{-1}$ ) and TMV- 2 (10.48 $\left.\mathrm{q} \mathrm{ha}^{-1}\right)$. Increase in the pod yield was due to increase in the growth parameters viz., number of branches, total dry matter, CGR, leaf area, LAI and LAD. Increase in the growth parameter provides better translocation of photosynthates to the sink and thereby, increases the pod yield. Thus, variation in the growth parameters varies the pod yield between the genotypes. Mohite et al., (2017) and Naik et al., (2018) also obtained similar results.

The pod yield decreased to 59.63 per plant with delay in sowing from II fortnight of June to I fortnight of August. The crop sown 
during II fortnight of June recorded significantly higher pod yield (15.20 q ha $\left.{ }^{-1}\right)$, which was due to favorable weather conditions prevailed during crop growth period and similar findings were reported by Canavar and Kaynak (2008) and Bala et al., (2011). Chandrika et al., (2008) reported that the effect of rainfall was greater on vegetative growth of the crop under late sown conditions. Canavar and Kynak (2010) also opined that short- day conditions reduces the crop growth period and unsuitable conditions like lack of rainfall under delayed sowing are unfavourable to the crop growth due to stressed conditions and thereby, reduces the pod yield. Early sowing of groundnut rarely experiences moisture stress during reproductive stage, especially pod development stage under normal rainfall distribution and was found to be more beneficial compared to delayed sowing (Patel et al., 2013).

Kernel yield depends on the pod yield and shelling per cent. Significantly higher kernel yield was recorded in the genotype GKVK-5 (12.17 q ha ${ }^{-1}$ ) (Table 3) due to better shelling per cent (72.65). However, higher number of pods per plant was observed in G2-52 (13.34) and lower in TMV-2 (7.73). This might be due to the genetic characteristic of the genotype (Mohite et al., 2017).

Kernel yield was found significantly higher when the crop was sown during II fortnight of June (11.93 q ha ${ }^{-1}$ ) (Table 3) than delayed sowing during I fortnight of August (7.69 q $\mathrm{ha}^{-1}$ ). This was due to the higher pod yield and shelling per cent.

Thus, it can be concluded that, the early sowing (II fortnight of June) can produce higher pod yield due to better vegetative growth, which can translocate photosynthates to the sink and can escape moisture stress conditions during critical growth period, compared to delayed sowing (I fortnight of August). The genotype GKVK-5 was found to perform better compared to G2-52, GPBD-4 and TMV-2, which produced higher pod yield, due to its genotypic characteristics

\section{References}

Agarwal, K. K., Jain, K. K., Sharma, R. Sand Kashyad, N. L. 1996. Response of winter niger (Guizotia abyssinia) to sowing time and fertility levels. Oilseeds Research. 13: 122-123.

Bala, H. M. B., Ogunlela, V. B., Kuchinda, N. C and Tanimu, B. 2011. Response of two groundnut (Arachis hypogaea $\mathrm{L}$.) varieties to sowing date and NPK fertilizer rate I a semi- arid environment: Yield and yield attributes. Asian Journal of Crop Science. 3: 130-140.

Banik, N. C., Nath, R and Chakraborty, P. K. 2009. Effect of dates of sowing on growth and yield of groundnut crop.Journal of Crop Weed. 5: 59-62.

Bhargavi, H., Srinivasa Reddy, M., Tirumala Reddy, S., Kavitha, P., VijayaBhaskra Reddy, V and Ramesh Babu, P. V. 2016. Productivity of groundnut (Arachis hypogea L.) as influenced by varieties and plant densities. Journal of Oilseeds Research. 33: 83-86.

Canavar, O and Kaynak, M. A. 2008. Effect of different planting dates on yield and yield components of groundnut (Arachis hypogea L.). Turk Journal of Agriculture. 32: 521-528.

Canavar, O and Kaynak, M. A.2010.Growing degree day and sunshine radiation effects on peanut pod yield and growth. African Journal of Biotechnology. 9: 2234-2241.

Chandrika, V., Parameshwari, $\mathrm{P}$ and Sreenivas, G. 2008. Effect of sowing time and rainfall distribution on yield of rainfed groundnut (Arachis 
hypogeal L.) in southern agroclimatic zone of Andhra Pradesh.Legume Research. 31: 54-56.

Kumar, B. N. M., Basavegowda, Vyakaranahal, B. S., Deshpande, V. K and Kenchanagowdar, P. V.2011. Influence of sowing dates on production of seed yield in niger (Guizotia abyssinia). Karnataka Journal of Agricultural Sciences. 24: 289-293.

Mohite, U. A., Mohite, A. B and Jadhav, Y. R. 2017. Effect of sowing windows on growth and yield of groundnut varieties during Kharif season. Contemporary Research in India. 7: 189-192.

Nagaeswara Rao. 1992. Some crop physiological approaches for groundnut improvement. Journal of Oilseeds Research. 9: 281-296.

Naik, A. H. K., Pallavi, N and Sannathimmappa, H. G. 2018. Performance of different SpanishType groundnut varieties suitable under Central dry zone of Karnataka, India. International Journal of Current Microbiology and Applied Sciences. 7: 1394-1397.

Patel, H. R., Lunagaria, M. M., Krande, B. I., Vyas Pandey., Yadav, S. B., Shah, A.V., Rao, V. U. M and Nareshkumar, S. 2013. Impact of projected climate change on groundnut in Gujarat. Journal of Agrometeorology. 15: 1-4.

\section{How to cite this article:}

Raagavalli, K., T. M.Soumya, H.K. Veeranna, S.P. Nataraju and Narayanswamy, H. 2019. Effect of Sowing Windows on Growth and Yield of Groundnut (Arachis hypogaea L.) Genotypes. Int.J.Curr.Microbiol.App.Sci. 8(03): 59-67. doi: https://doi.org/10.20546/ijcmas.2019.803.009 